\title{
Financial sector development and economic growth in the Southern African Development Community region
}

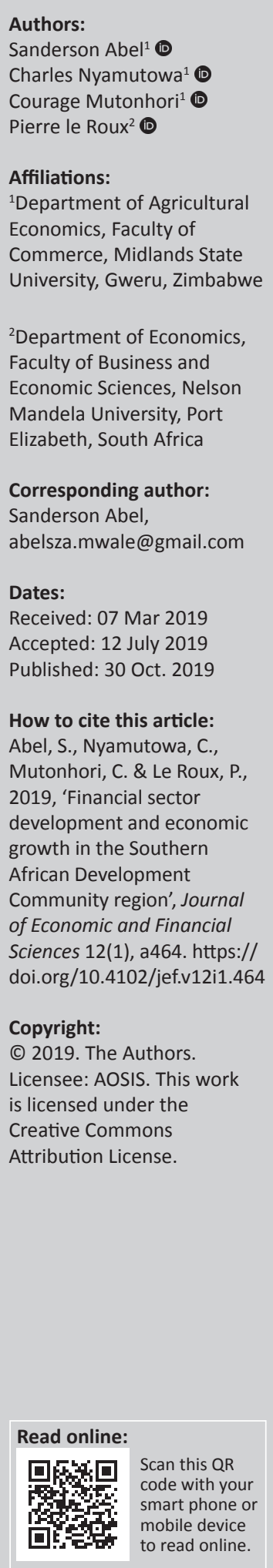

Orientation: The relationship between financial sector development and economic growth has been the subject of intense debate for some time. The debate has received substantial attention in both empirical and theoretical literature and remains inconclusive.

Research purpose: This study examines the relationship between financial sector development and economic growth in Southern African Development Community (SADC) contributing to the ongoing debate. The study uses the SADC as the laboratory case.

Motivation for the study: The protocol on finance and investment seems to foster harmonisation of the financial and investment policies in order to make them consistent with the objectives of SADC. Competent implementation of financial policies suggests that each country in the region should be able to bring sustainable economic growth and development. Southern African Development Community's protocol for finance and investment spells out objectives and actions that are meant to improve financial development.

Research approach/design and method: The study used the Fixed Effects panel data approach and seemingly unrelated regression estimators (SURE) methods covering the period 1990 to 2014. Financial development was measured using money supply with control variables such as inflation, interest rates and country openness. Other growth related variables that were used include population growth rate and gross fixed capital formation.

Main findings: Results from the fixed-effects model showed that inflation; gross fixed capital formation; and openness of a country significantly influenced economic growth. The fixed effects result confirmed a positive association between financial sector development and economic growth in SADC region. The SURE results show that there is heterogeneity across the SADC countries.

Practical/managerial implication: The study shows that SADC countries should improve the financial sector landscape to enhance economic growth. The results imply that among the SADC convergence criteria, emphasis should be placed on stabilising the financial sector landscape.

Contribution/value-add: The study has contributed to the debate on the relationship between financial sector developments especially more in the context of Southern African Economic Community which is working towards achieving a convergence macroeconomic framework.

Keywords: financial sector development; economic growth; Southern African development community; nexus; fixed effects.

\section{Introduction}

Financial sector (FS) development is a way of enriching and firming the provision of services in the FS with the aim of satisfying economic agents' needs in an effective and efficient manner, thereby increasing the economic growth (FitzGerald 2006). Financial development stretches the range of financial services available, advances the accessibility of financial services to the public and also improves the efficiency and competitiveness of the sector. Furthermore, FS development through its connections with other sectors empowers economic agents with accumulated savings and some borrowed funds to start micro-enterprises, hence reduces unemployment and increases incomes. On the other hand, economic growth is an increase in the real gross domestic product (GDP) per capita or an outward shift in the production possibility frontier. Economic growth is a key method of plummeting poverty in developing countries such as Zimbabwe, South Africa, Malawi, Madagascar, Namibia, Zambia, Angola, Tanzania, Mozambique, Swaziland, Lesotho, 
DRC, Seychelles, Botswana and Mauritius (Southern African Development Community [SADC]).

This field of economics has been facing rapid investigations and there has been a long debate on the relationship between FS development and economic growth (Arayssi \& Fakih 2017; Bara \& Mudzingiri 2016; Chisunga 2015; Karlsson \& Mansson 2015; Mandiefe 2015; Odhiambo 2010; Rana \& Barua 2015; Sunde 2011, 2012). The debate has received substantial attention in both empirical and theoretical literature, with contradicting views emerging (Greenwood, Sanchez \& Wang 2010). There is empirical evidence in support of the financeled growth, which is known as the supply-leading response; others are in support of the growth-led finance known as the demand-following response; and others show a bi-directional causality response. Odhiambo (2005) observed a bidirectional causality relation between financial development and economic growth, whereas in one of his studies (2007), he found that financial development leads to economic growth (supply-leading response). Again, Odhiambo (2011) found that economic growth leads to financial development (demand-pulling response). Disparities in empirical findings indicate different institutional features, varied policies and implementation inconsistencies. Therefore, more research is needed in this area.

The FS has through the years declined and this has been inconsistent with the low economic growth in SADC (Committee of Central Bank Governors in SADC 2012). Furthermore, financial systems are inherently unstable, and whenever financial instability occurs, growth is likely to suffer. Recent financial crises have also shown us that with the increase in the interdependence of economies across the world, financial crises have become more costly because countries are more exposed to shocks occurring elsewhere in the world (Mathego \& Nikolaidou 2014). With the development of the FS, a number of channels through which a country can be impacted by shocks occurring in other countries also increased. The finance-growth nexus will be of great concern to policy-makers and government because if FS development has a positive effect on growth, poverty in the region will be reduced and accessibility of financial services to the public will be improved; hence, mobilisation of savings and investment is also increased thereby increasing incomes. In SADC, access to formal financial services is limited and people are forced to depend on risky and expensive informal services. If underdevelopment of the FS persists, this means people cannot participate fully in markets, they are unable to increase their incomes and their contribution to economic growth will be constrained. Failure of FS implies that allocation of capital will not be optimised and will not go to its most productive use and consequently low economic growth. Restructuring the financial system and review of institutions will be of great importance to the development of the region. The main objective of this study is to determine whether there is a relationship between FS development and economic growth.
Theory shows that there are a number of avenues through which development in the FS can boost economic growth. Mlambo Kasekende and Murinde (2012); Anyanwu (2010); and Levine (2005) argue that the FS can increase savings, thereby increasing the availability of resources for investment. They further argue that the FS can increase the productivity of investment as a result of high levels of savings. Thirdly, FS can be improved through monitoring of investments as well as ensuring corporate governance once finance has been provided by financial institutions. Finally, FS can lead to reduction in transaction cost which promotes specialisation, technological innovation and eventually growth. A number of studies have attempted to establish the relationship between financial development and growth. A review of the empirical literature shows conflicting conclusions based on the methodologies used as well as the assumptions of either homogeneity or heterogeneity made concerning the countries used in study samples (Chisunga 2015; Karlsson \& Mansson 2015). The main objective of this study is to determine whether there is a relationship between FS development and economic growth.

\section{Stylised facts about Southern African Development Community financial development}

The Southern African Development Community has its origins in the Southern African Development Coordination Conference (SADCC), which was established in 1980. The declaration and treaty establishing SADC was signed in 1992 as a replacement to the SADCC. The vision of SADC is for a regional community in which the people of Southern Africa can realise economic well-being, improved living standards and quality of life, freedom, social justice, peace and security. The SADC's mission is to 'advance feasible and reasonable monetary development through proficient gainful frameworks with the goal that the area rises as focused'.

According to Allen, Otchere and Senbet (2011), the late 1980s witnessed several countries in SADC moving towards economic and FS reforms following the adoption of the Structural Adjustment Programme and Economic Recovery Programme which were supported by the International Monetary Fund (IMF) and the World Bank. Poor economic performance of SADC was blamed on the regression postindependent economic and financial system. Second cause was the nature of treaty since SADCC up to 1992 was a conference, and hence no actual binding economic treaty was signed and implemented. One of the core focus of reforms was the financial system developments which further economic growth. Inadequate FS development was argued to be among other central reasons answerable for the slow growth process in the region. This is because a well-developed and efficient financial system results in mobilising and channelling resources not only to productive areas but also to areas that are more risky but promising, and these processes could include economic growth (Allen et al. 2011). 


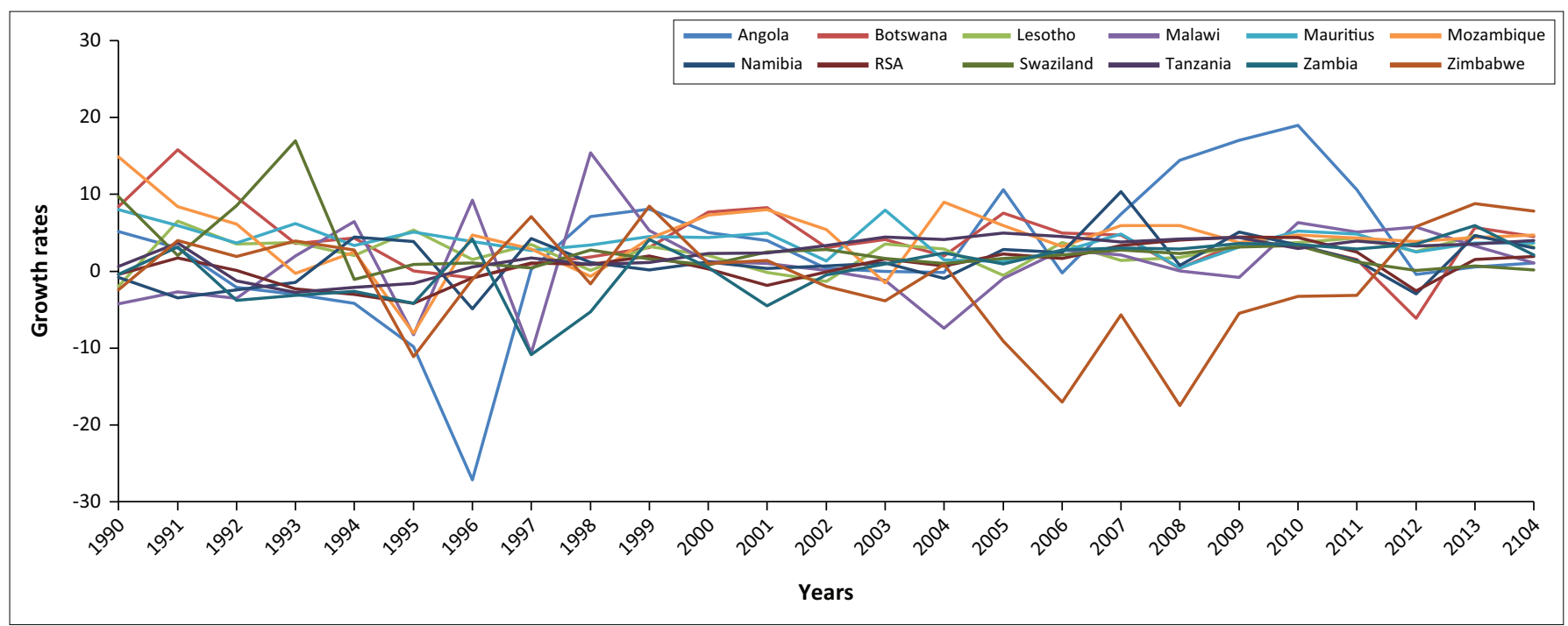

FIGURE 1: Southern African Development Community growth rates (1990-2014).

The protocol on finance and investment seems to foster harmonisation of the financial and investment policies in order to make them consistent with the objectives of SADC (IMF 2014). Competent implementation of financial policies suggests that each country in the region should be able to bring sustainable economic growth and development. Southern African Development Community's (2006) protocol for finance and investment spells out objectives and actions that are meant to improve financial development. Such strategies, objectives and actions encouraged the cooperation of state parties to ensure efficient exchange controls and effective coordination among state central banks. Working together on bank supervision among central banks and together in the activities of Development Financial Institutions (DFIs) in the region eases the development of capital and financial markets and as well as improves the stock exchange in the SADC region.

Figure 1 shows the growth rates of the SADC countries between 1990 and 2014. The average growth rate was below $10 \%$ over the whole period. This augurs well with the SADC converge criterion that has set the average economic growth rate at $7 \%$ per annum.

\section{Literature review}

This section reviews related literature on the association of FS development and economic growth. Bist (2018) estimated the long-run relationship between financial development and economic growth. A panel unit root and a panel co-integration of 16 selected low-income countries were adopted for the period covering 20 years, that is, from 1994 to 2014. Modified and dynamic ordinary least square technique was used to estimate the long-run relationship, and results show that there exists a cross-section dependence on countries. A clear support for the hypothesis that there exists a long-run co-integration relationship between finance and growth was revealed by the Pedroni's panel co-integration analysis. Results of the long-run estimates indicate that financial development has a significant positive impact on economic growth. Robustness of results was also estimated with time series analysis on a single-country basis. Results also confirmed a positive relationship existing between financial development and economic growth in most countries. Similarly, it was found that flow of credit to the private sector was very low in this region. Bist advised policymakers to place more emphasis on the policies that provide favourable environment for the private sector to grow. Arayssi and Fakih (2017) researched the finance-growth nexus. Their objective was to find a connection between financial development and economic growth in Kenya over the period 1960-2013. A Cobb-Douglas production function was adopted, while the vector autoregressive (VAR) model was used to determine the causal relationship between financial development and economic development. Three alternative production function representations were suggested, namely a basic model including financial development and inflation along with capital and labour, a variant adding foreign direct investment (FDI) and a third focusing on the interaction between financial development and FDI. The results show that financial development is a byproduct of growth. The interaction between FDI and financial development stimulates growth as confirmed by empirical analysis. A bidirectional causality between growth and the labour force was found. Policy-makers in Kenya can obtain fruitful impacts of FDI to enhance growth by improving the role of financial development.

Ofori-Appiah (2016) examined the nexus between financial development and economic growth in Ghana over the period 1970-2013. An error correction model was developed within the Autoregressive Distributed Lag (ARDL) framework to explore the long-run and short-run nexus between financial development and economic growth. Five different measures of financial development such as credit to the private sector, ratio of narrow money to broad money, broad money, narrow money and domestic credit (DC) were considered in the model. They also investigated whether there are other determinants of economic growth. Results confirmed evidence of both long-run relationship and short-run 
dynamics which was found among the various financial development indicators and economic growth. Furthermore, results showed that DC, ratio of narrow money to broad money, broad money, narrow money and credit to the private sector influenced economic growth in the long and short run. Inflation and government consumption expenditure were found to impede economic growth in the long run and short run. Contrarily, trade openness, capital stock and FDI were found to have positive effects on economic growth in both the long run and the short run. On the basis of empirical evidence, policies to improve the accessibility of affordable credit by the private sector, including small and medium scale enterprises should be enforced. Rana and Barua (2015) examined the relationship between financial development and economic growth. Panel data for five emerging South Asian countries (Bangladesh, India, Nepal, Pakistan and Sri Lanka) were used in the analysis. They collected heterogeneous panel data from the World Bank for the period 1974-2012. Economic growth was captured by the GDP growth rate, while financial development was extracted using DC, total debt services, gross domestic savings, broad money and trade balance. The model employed fixed effect panel regression; time fixed effect, cross-sectional dependence, heteroscedasticity, serial correlation and co-integration were tested for model fitness. Domestic savings and total debt services have a significant impact on the economic development. Amusingly, DC, trade balance, and broad money have no significant influence on nurturing economic growth.

Chinedua and Amaka (2015) assessed the impact of financial development on economic growth in Nigeria. They used time series data from 1970 to 2012, and the ARDL bounds testing approach to co-integration was utilised. Results from the ARDL model indicated that the variables were cointegrated, while the error correction term appeared significant and confirmed that short-run disequilibria were corrected up to about 50\% annually. Results were in support of the finance-growth nexus of the McKinnon-Shaw hypothesis, while trade liberalisation variables were found to be negative and they insignificantly impact real GDP (RGDP) in the long run. Financial development policy plays a significant role in stimulating economic growth in the long run and vice versa in the short run. Trade liberalisation policies have not been robust enough to impact on economic growth both in the short run and the long run. The error correction model has been stable over the study period although it indicates high rate of adjustment to equilibrium. Findings revealed that financial development exerts a positive and significant impact on economic growth in the long run, while trade liberalisation variables exert a negative impact on economic growth in the long run. Empirical analysis agreed that financial development policies influence economic growth in the long run and not in the short run. In addition, the study recommends the urgent need to implement policies that will strengthen the deposit mobilisation and intermediation efforts in the banking system in order to deepen the financial system. Policy-makers should focus on long-run policies that promote sustainable economic growth. Moreover, Nigerian trade performance should be improved through economic diversification and further availability of funds to the private sector at competitive interest rates in order to produce internationally competitive products. The financial system needs to be deepened by the strengthening of deposit mobilisation so as to achieve sustainable economic growth. Finally, there should be creation of modern financial institutions and strengthening of the stock markets to enhance confidence of investors in the economy. Karlsson and Mansson (2015) revisited the nexus of financial development and economic growth. The study employed wavelet analysis on the data of 10 Asian economies from 1971 to 2013. The core idea of their paper was to examine both the directions of causality between financial development and economic growth and also the signs of the relationships at different time scales. Their paper also aimed to test if there was a difference in the relationship between developing and developed economies in the Asian region. A wavelet decomposition was employed to cater for time-scale issues regarding financial development and economic growth. Firstly, results confirmed that financial development in general leads to economic growth for both developing and developed economies in the region; secondly, there is a bidirectional causality between financial development and economic growth, which nonetheless applies generally only for high-income economies; thirdly, positive effects of the financial development on economic growth, however, hold for the long run. Finally, negative effects of the financial development on the economic activity were observed in the short run, especially for the low- and lower-middle income economies. Implications of the paper also suggested that financial liberalisation for economies at an early economic development stage can harm the real economy in the short run because of a likely association of the FS's expansion to financial crisis.

Mandiefe (2015) investigated the impact of FS development on economic growth. His study attempted to verify the shortrun and the long-run impact of FS development on economic growth and also to verify the gap of financial development that separates Cameroon and an emergent country like South Africa (RSA). Annual time-series data covering the period from 1980 to 2010 for both countries were used. The vector error correction model was used. Real GDP growth (RGDP) was a model-dependent variable, and there were three main variables indicating financial development. These variables were derived from broad money, base money and bank credit to private sector. A long-run relationship between economic growth and financial development was noticed in Cameroon, while for RSA a short-run relationship between bank deposits and economic growth was found and also a longrun relationship between economic growth and financial development was noticed. The RSA economy moves towards its long-run equilibrium faster after economic shocks mainly because of its good financially developed economy. A gap of 0.26 was noticed, and this means that for the economy of Cameroon to be emergent, the speed of long-run adjustment 
should increase by 0.26 . Mathenge and Nikolaidon (2014) examined the effect of financial structure on economic growth in the SSA and its sample was built upon low- and middleincome countries. They used dynamic panel estimation techniques and investigated both the short-run and the longrun effects of financial structure on growth, focusing on 14 SSA countries over the period 1980-2014. The results indicate that financial structure is not significant in explaining growth in the region. Moreover, the study was robust to sample groupings, and the results do not change when they have excluded countries with better developed financial systems relative to other countries in the sample. This goes hand in hand with a study by Levine (2002) of 48 developed and less developed countries, which shows that financial structure is irrelevant in explaining growth, and these results were robust to a number of sensitivity tests that included different measures of financial structure. Bara and Mudzingiri (2016), empirically established the causal relationship between financial innovation and economic growth in SADC. They used the ARDL model, estimated by pooled mean group and dynamic effects. Results confirmed that financial innovation is positively related to economic growth in the long run. The long-run estimators, however, show the existence of a weak relationship. Panel Granger causality tests established that there is no causality in any direction, between financial innovation and growth in both the short run and the long run.

Chisunga (2015) investigated the impact of FS development on economic growth in Zimbabwe. His research utilised secondary data for the period 1995-2008, and the Granger causality test was used to test the causality between economic growth and four FS development indicators (Liquidity liabilities scaled to GDP, Stock market capitalisation scaled to GDP, Stock trade total value scale to GDP and DC to private sector). Johansen's co-integration approach was used to test the long-run relationship between economic growth and FS development indicators. Granger causality test results confirmed causality running from economic growth to FS development. In addition, results agree with some empirical evidence that postulates that the Granger relationship runs from economic growth to financial development and there is a positive relationship in the long run. The study provides empirical evidence that FS development and economic growth are positively related in the long run. Therefore, the author recommends Zimbabweans to implement policies that foster economic growth and this will subsequently promote FS development.

Sunde (2012) explored the link between FS development and economic growth in South Africa. The author applied the co-integration and error correction modelling as well as the Granger causality tests. Economic growth was determined by FS variables and control variables such as inflation, the exchange rate and real interest rates. Furthermore, the Granger causality tests showed that, in general, there is a bidirectional relationship between economic growth and FS development in South Africa. This relationship implies that if the economy grows, the FS will also grow, and vice versa. Sunde (2011) examined the relationship between FS development and economic growth in Namibia. A relationship between FS and economic growth was established. Using the Granger causality tests, the results showed that the causality between financial development and economic growth was by and large in both directions, which means that when the economy grows, the FS may respond positively. Conversely, growth of the FS can actually drive or underlie economic growth. The author concluded that where causality runs from the FS to economic growth, then the development and growth of the FS could make the Namibian economy grow faster than it does currently. As there are few banks in the economy, this can lead them engaging in monopolistic behaviour as they earn high profits. Thus, if the country was to improve access to banking services through increased competition or more branches, this could unlock the growth potential of the economy. Sunde (2011) also concluded that countries with a less developed financial system tend to experience demand where economic growth causes the FS to develop. In South Africa, Odhiambo (2010) examined the relationship between financial development, investment and economic growth using the ARDL bounds testing procedure. The results of the study showed that generally economic growth has a strong influence on FS development and that there is a unidirectional causal flow from growth to investment, which then Granger-causes financial development. The study recommended that South Africa should therefore intensify its pro-growth policies in order to bolster investment and financial development.

\section{Research methodology}

To empirically examine the relationship between financial development and economic growth, this article adopted a standard growth model, following the work of Levine (2002). The following authors have also used the same model in the recent past: Kilimani (2009); Law and Singh (2014); Mathego and Nikolaidou (2014); Baragas (2016); and Rateiwa and Aziakpono (2017).

The standard growth model establishes a behavioural relationship among the variables of interest, from which we can derive a production function. The article assumes a Cobb-Douglas production function that uses capital $(K)$ and labour $(L)$ in the production of output $(Y)$. It takes the form:

$$
Y=f(A, K, L)
$$

where $A$ is the measure of technological efficiency.

In order to identify the role of FS, we augment the above equation with indicators of FS. Augmenting Equation (1) with the FS indicator gives us an empirical equation (Equation 2).

The methodology applied in this article closely follows the research performed by King and Levine (1993); Kilimani (2009); Mathenge and Nikolaidon (2014) and Rateiwa and 
Aziakpono (2017) in the investigation of the relationship existing between financial development and economic growth. The empirical model has been consistently used by many researchers in the past, and it is currently being much appreciated in the work of financial development and economic growth. Taking this into account, the model becomes:

$\mathrm{RGDP}_{i, t}=\beta_{0}+\beta_{1} M 2_{i, t}+\beta_{2} \mathrm{GFCF}_{i, t}+\beta_{3} \mathrm{INF}_{i, t}+\beta_{4} \mathrm{OC}_{i, t}+\beta_{5} \mathrm{DC}_{i, t}+\varepsilon_{i, t}$

[Eqn 2]

\section{Definition and justification of variables}

Real GDP per Capita Growth ( RGDP $_{\text {it }}$ ) - This article used RGDP per capita growth as a measure of economic growth. Real GDP per capita is obtained by deflating nominal GDP with consumer price index (CPI) divided by the total population in the country. An increase in RGDP per capita growth signals growth in the economy as it accounts for general welfare of a country's citizens. Use of RGDP per capita growth is in line with studies by King and Levine (1993) and Kilimani (2009).

M2 money supply as a \% of GDP (M2 $\left.2_{\mathrm{it}}\right)$ - Money supply (M2) as a percentage of GDP measures the size of the formal financial intermediary sector relative to economic activity. M2 has been included in the studies of the following authors: King and Levine (1993); Mathenge and Nikolaidon (2014); and Rateiwa and Aziakpono (2017). M2 can take any sign.

Gross Fixed Capital Formation $\left(\mathrm{GFCF}_{\mathrm{it}}\right)-$ Gross fixed capital formation is used as a proxy of physical capital or investment, and it captures the amount of capital required in a nation's productive activities. Investment, as proposed by Solow (1956), is positively related to economic growth.

Inflation $\left(\mathrm{INFL}_{\mathrm{it}}\right)$ - Inflation is a persistent and sustained increase in general price level, and high levels of inflation distort economic activities and reduce investment in productive enterprises thus reducing economic growth (Allen \& Ndikumana 1998). Inflation is measured in the analysis by CPI.

Openness of a country $\left(\mathrm{OC}_{\mathrm{it}}\right)$ - Weight of global trade on growth is captured by the openness of a country variable which is expressed as the sum of imports and exports taken as a percentage of GDP (Levine, Loayza \& Beck 2000). The effect of trade is expected to be positive as trade brings in flow of ideas, skills and specialisation. On the other hand, it can be negative or positive, and hence its net effects can only be determined empirically. Inflation, population growth rate and openness to trade are added to control for the possible effects of other growth determining factors. Furthermore, inflation, population growth rate and openness to trade were also considered in order to control for omitted variable bias.

Domestic credit to the private sector (DC) - Credit to the private sector can have a positive impact on GDP (Iqbal,
Ahmad \& Hussain 2012). It will be interesting to examine this perceived relationship with particular reference to SADC. This is another measure of FS development.

The conventionally used methodology has been the ARDL, Fixed Effects and generalised methods of moments (GMM), but this study will use a further advancement to seemingly unrelated regression estimators (SURE) (seemingly unrelated coefficients) to capture each country's heterogeneity. The study is built upon the panel data of 12 SADC member states for the period 1990-2014 with RGDP per capita growth as its dependent variable, while FS indicators and control variables are independent variables. The indicator used to measure FS development was money supply and DC to the private sector expressed as a percentage of GDP. Research used gross fixed capital formation (GFCF) to measure the level of investment, hence economic growth. Inflation, real interest rates, openness of a country and population growth rate were used as control variables.

\section{Model estimation procedure}

A panel data econometric technique is adopted for the analysis. The object of the technique is to overcome weakness of most cross-country panel data approaches. The regression equation is a linear model. Two panel data methodologies were used in the econometric analysis, namely fixed/random effects and SURE.

Hausman test results will determine whether fixed effects or random effects model is best in dealing with the problem of homogeneity. Essentially, Hausman test analyses if there is a correlation between the unique errors and the regressors in the model. The null hypothesis is that there is no correlation between the two. If the $p$-value is small (less than 0.05), we may reject the null hypothesis. Furthermore, the test evaluates the consistency of an estimator when compared to an alternative, less efficient estimator which the statistical model corresponds to that data. Seemingly unrelated regression estimators is best in dealing with cross-sectional dependence.

The study also conducted three unit root tests such as Levin-Lin-Chu, Im-Pesaran- Shin and Bretuing on the data to determine whether the variables have unit roots or are stationary. The research used annual data (constant 2000 US\$) obtained from World Bank's Africa Development Indicators, and because of serious gaps in the data collected from above sources, alternative data sources were used, including United Nations Conference on Trade and Development (UNCTAD) and the central banks in SADC.

\section{Result presentation and analysis}

The main purpose of this research was to investigate the relationship existing between FS development and economic growth in SADC. Research findings were based on financial indicators and control variables obtained from World Bank's Africa Development Indicators. Statistical measures and 
analytical techniques are used in this article to discuss, analyse and interpret the findings. Main areas of discussion include interpretation of descriptive statistics, construction of the correlation matrix and interpretation of random effect and seemingly unrelated regression results. The descriptive statistics of the variables are summarised in Table 1.

The descriptive statistics in Table 1 show that all variables except inflation and GFCF have low standard deviations. Low standard deviations are desired outcomes as they signal less spread among the data sets and efficiency.

Results show that all variables were stationary in their levels except inflation, interest rate, GFCF and openness of a country. Based on the Levin-Li-Chu test, they then became stationary after differencing. Im, Persanan and Shin results confirmed that all variables were stationary at level, while Bretuing test results confirmed that all variables were stationary at level except interest, inflation and GFCF which became stationary after first differencing.

Table 3 is a correlation matrix. A correlation matrix shows the magnitude of correlation. According to Gujarati (2008), the correlation among variables is problematic when it exceeds 0.8. Based on this criterion, the results show that there is no problem of multicollinearity.

Hausman test is often described as a test for model misspecification. It is used to differentiate between fixed

TABLE 1: Descriptive statistics by group.

\begin{tabular}{lccccc}
\hline Variable & Obs & Mean & SD & Min & Max \\
\hline RGDP & 275 & 2.034585 & 4.937298 & -27.14234 & 18.99058 \\
INFL & 275 & 60.7733 & 375.5156 & -27.04865 & 5399.526 \\
M2 & 275 & 32.40247 & 20.17815 & 4.284558 & 118.9997 \\
GFCF & 275 & $2.63 \mathrm{E}+10$ & $1.30 \mathrm{E}+08$ & $1.12 \mathrm{E}+12$ & $1.12 \mathrm{E}+12$ \\
OC & 275 & 89.5373 & $3.82 \mathrm{E}+01$ & $3.35 \mathrm{E}+01$ & $2.10 \mathrm{E}+02$ \\
DC & 275 & 36.65271 & 51.65385 & -79.09235 & 192.66 \\
\hline
\end{tabular}

RGDP, real GDP; INFL, inflation; GFCF, gross fixed capital formation; DC, domestic credit; $\mathrm{SD}$, standard deviation; $\mathrm{OC}$, openness of a country; Min, minimum; Max, maximum.

TABLE 2: Unit root tests.

\begin{tabular}{lccc}
\hline Variables & Levin-Li Chu & Im, Persanan and Shin & Bretuing \\
\hline RGDP & $\mathrm{I}(0)$ & $\mathrm{I}(0)$ & $\mathrm{I}(0)$ \\
INFL & $\mathrm{I}(1)$ & $\mathrm{I}(0)$ & $\mathrm{I}(1)$ \\
M2 & $\mathrm{I}(0)$ & $\mathrm{I}(0)$ & $\mathrm{I}(0)$ \\
GFCF & $\mathrm{I}(1)$ & $\mathrm{I}(0)$ & $\mathrm{I}(1)$ \\
OC & $\mathrm{I}(0)$ & $\mathrm{I}(0)$ & $\mathrm{I}(1)$ \\
DC & $\mathrm{I}(0)$ & $\mathrm{I}(0)$ & $\mathrm{I}(0)$ \\
\hline
\end{tabular}

RGDP, real GDP; INFL, inflation; GFCF, gross fixed capital formation; DC, domestic credit; OC, openness of a country.

TABLE 3: Correlation matrix of vector explanatory variables

\begin{tabular}{lcccccc}
\hline Variable & RGDP & OC & M2 & INFL & GFCF & DC \\
\hline RGDP & 1 & 0.075376 & 0.048264 & -0.06458 & 0.129373 & -0.13273 \\
OC & 0.075376 & 1 & 0.187958 & -0.00318 & 0.028328 & -0.24216 \\
M2 & 0.048264 & 0.187958 & 1 & 0.004281 & -0.00595 & 0.615274 \\
INFL & -0.06458 & -0.00318 & 0.004281 & 1 & -0.01906 & 0.001648 \\
GFCF & 0.129373 & 0.028328 & -0.00595 & -0.01906 & 1 & 0.009099 \\
DC & -0.13273 & -0.24216 & 0.615274 & 0.001648 & 0.009099 & 1 \\
\hline RGDP, real GDP; DC, domestic credit; OC, openness of a country; INF, Inflation; GFCF gross
\end{tabular}
fixed capital formation. effects and random effects. The chi-square value is more than 0.05 at all conventional significance levels, so we fail to reject the null hypothesis and conclude that the random effects model is more appropriate.

The results from the random effects model show that there is a positive relationship between FS development and economic growth. This means that developments in the FS positively affect economic growth. The result that money supply has a positive significant effect on economic growth is supported by a number of studies (Nouri \& Samimi 2011; Ogunmuyiwa \& Ekone 2010; Owolabi 2014; Uduakobong 2014). In a study of Nigeria, Ogunmuyiwa and Ekone (2010) found that money supply has a positive effect on economic growth. Similarly Owolabi (2014) found a positive significant relationship between money supply and economic growth in Nigeria, while Uduakobong (2014) in a study of Nigeria established that there was no relationship between money supply and economic growth. Nouri and Samimi (2011) discovered that there was a positive significant relationship between money supply and economic growth in Iran.

The study has also found that DC to the private sector has a negative effect on economic growth in the region. This implies that an increase in DC to the private sector reduces economic growth. This result is not surprising given the conflicting results that have since been established in literature. Iqbal et al. (2012) found that credit to the private sector has significant impact upon economic growth in the long run but also in the short run. The same results were established by Cappiello et al. (2010) who found that a change in loans growth has a positive significant impact on GDP in their study of Europe. This is contrary to the findings of Demetriades and James (2011) who established that there was no link between private credit and economic growth. Similar results were reported in the studies by Estrada, Park and Kamayandi (2010) and Kumar (2011).

Gross fixed capital formation has a positive coefficient, which shows that investment in fixed capital yields expected positive results in the SADC region. A positive coefficient could mean that the region is investing in the appropriate infrastructure that promotes economic growth. Similar results were established in a study by Kanu and Ozurumba (2014) who found that GFCF exerts wide and significant influence on economic growth. On the other hand, Uneze (2013) found bi-direct causality between capital formation

TABLE 4: Estimation of the model with random effects.

\begin{tabular}{lc}
\hline Variable & Coefficient \\
\hline C & $1.7889091(0.017)^{* *}$ \\
INFL & $-0.005430(0.000)^{* * *}$ \\
M2 & $0.0433831(0.029)^{* *}$ \\
GFCF & $5.10 \mathrm{E}-12(0.009)^{* * *}$ \\
OC & $0.0015182(0.852)$ \\
DC & $-0.0244523(0.001)^{* * *}$ \\
$R^{2}$ & 0.2441 \\
\hline INFL, inflation; GFCF, gross fixed capital formation; DC, domestic credit; OC, openness of a \\
country.
\end{tabular}


and economic growth. The results implied that increase in economic growth leads to an increase in the capital formation which further boosts growth. The results were applied for both private fixed capital formation and gross capital formation.

Inflation had a negative coefficient and was significant, showing that persistently high inflation has had an adverse impact on economic growth in the SADC region. Similar results were established by other studies (Antwi 2013; Ditimi et al. 2012; Faria \& Carneiro 2001).

Table 5 regression results show similar results to those that were obtained using the random effects model; openness and inflation are the ones that are insignificant.

The results from the seemingly unrelated regression (Table 6) show that SADC countries are heterogeneous in terms of their determinants of real gross domestic product. Of interest is that Angola is the only country with significant money supply, while credit to the private sector is significant only in Tanzania. Another monetary phenomenon is that inflation is a major determinant of growth in Angola, Malawi, Namibia, South Africa and Tanzania.

\section{Summary}

The study aimed to investigate the relationship between FS development and economic growth in SADC. Before all the techniques were conducted, unit root tests were conducted to determine how stationary all the variables were. It was revealed that some of the variables were not stationary and could only be stationary after being differenced. This review

TABLE 5: Model with variables adjusted for stationarity.

\begin{tabular}{lc}
\hline Dependent variable RGDP & Coefficient \\
\hline C & $1.820226(0.0288)$ \\
OC & $-0.005044(0.5565)$ \\
M2 & $0.054299(0.009)$ \\
D2INFL & $-0.000397(0.3216)$ \\
D2GFCF & $1.27 E-11(0.0358)$ \\
DC & $-0.024704(0.0016)$ \\
\hline
\end{tabular}

RGDP, real gross domestic product; INFL, inflation; GFCF, gross fixed capital formation; DC, domestic credit; OC, openness of a country. showed that FS development has a positive influence on economic growth. It was noted that FS development promotes economic growth by strengthening competition and stimulating innovation.

Results from the random effects panel regressions showed that inflation, GFCF, money supply and DC to the private sector were the only significant variables, while the SURE model revealed mixed results, which shows that there is heterogeneity across the SADC countries.

Southern African Development Community countries should facilitate access to finance by increasing the availability of the range of financial services to a broader set of economic agents and sectors in the economy. One way of improving finance is by promoting the use of information and communication technologies (ICTs) in the FS and the growth of specialised microfinance institutions. Promoting the use of technology in the FS technological innovation has a potential transformative role in widening affordable financial services mainly in the rural areas.

According to Odhiambo (2010), it is recommended that progrowth policies should be deepened in order to encourage investment and financial development. Southern African Development Community countries should aim to develop financial institutions in order to improve their financial services and products, mainly in rural areas where a small number of financial institutions exist such as banks and microfinance organisations. This would improve liquidity in the economy and also access to funding by small-scale business enterprises.

Southern African Development Community countries should improve access to financial services and banking. Access should be not only in towns but also equally in rural areas. Policy-makers in SADC economies should explore the promotion of plastic money, such as mobile banking, particularly in rural areas. Furthermore, access should not always be in the form of a physical presence of banks but should also include modern electronics that can be easily accessed by the less sophisticated citizens. In urban areas, there is a need for improvements of institutions such as banks

TABLE 6: Seemingly unrelated regression estimators results.

\begin{tabular}{|c|c|c|c|c|c|c|c|c|c|c|c|}
\hline Variable & Angola & Botswana & Lesotho & Malawi & Mauritius & Mozambique & Namibia & South Africa & Tanzania & Zambia & Zimbabwe \\
\hline OC & $\begin{array}{c}0.016157 \\
(0.877)\end{array}$ & $\begin{array}{c}0.2801018 \\
(0.008)\end{array}$ & $\begin{array}{c}0.0032062 \\
(0.934)\end{array}$ & $\begin{array}{c}-0.141646 \\
(0.250)\end{array}$ & $\begin{array}{c}-0.053023 \\
(0.410)\end{array}$ & $\begin{array}{c}0.0754136 \\
(0.506)\end{array}$ & $\begin{array}{c}-0.118884 \\
(0.064)\end{array}$ & $\begin{array}{c}0.2189644 \\
(0.004)\end{array}$ & $\begin{array}{c}0.0316746 \\
(0.291)\end{array}$ & $\begin{array}{c}-0.144084 \\
(0.405)\end{array}$ & $\begin{array}{c}-0.017255 \\
(0.889)\end{array}$ \\
\hline INFL & $\begin{array}{c}-0.005906 \\
(0.000)\end{array}$ & $\begin{array}{c}0.1506091 \\
(0.199)\end{array}$ & $\begin{array}{c}0.0439039 \\
(0.743)\end{array}$ & $\begin{array}{c}0.1355111 \\
(0.077)\end{array}$ & $\begin{array}{c}0.1314665 \\
(0.469)\end{array}$ & $\begin{array}{c}0.0262533 \\
(0.379)\end{array}$ & $\begin{array}{c}-0.1879297 \\
(0.081)\end{array}$ & $\begin{array}{c}-0.371608 \\
(0.039)\end{array}$ & $\begin{array}{c}-0.1807906 \\
(0.000)\end{array}$ & $\begin{array}{c}0.0156783 \\
(0.596)\end{array}$ & $\begin{array}{c}0.1707672 \\
(0.364)\end{array}$ \\
\hline M2 & $\begin{array}{c}0.7438756 \\
(0.072)\end{array}$ & $\begin{array}{c}0.0514571 \\
(0.664)\end{array}$ & $\begin{array}{c}0.0948093 \\
(0.630)\end{array}$ & $\begin{array}{c}0.4795212 \\
(0.220)\end{array}$ & $\begin{array}{c}-0.023945 \\
(0.356)\end{array}$ & $\begin{array}{c}-0.5139939 \\
(0.153)\end{array}$ & $\begin{array}{c}-0.137888 \\
(0.264)\end{array}$ & $\begin{array}{c}-0.035007 \\
(0.253)\end{array}$ & $\begin{array}{c}-0.1189753 \\
(0.392)\end{array}$ & $\begin{array}{c}0.1829502 \\
(0.389)\end{array}$ & $\begin{array}{c}-0.1566694 \\
(0.428)\end{array}$ \\
\hline DC & $\begin{array}{c}-0.075238 \\
(0.562)\end{array}$ & $\begin{array}{c}-0.035374 \\
(0.505)\end{array}$ & $\begin{array}{c}-0.029590 \\
(0.615)\end{array}$ & $\begin{array}{c}0.0265781 \\
(0.903)\end{array}$ & $\begin{array}{c}-0.042089 \\
(0.374)\end{array}$ & $\begin{array}{c}0.3210373 \\
(0.124)\end{array}$ & $\begin{array}{c}0.0881783 \\
(0.309)\end{array}$ & $\begin{array}{c}-0.0176973 \\
(0.501)\end{array}$ & $\begin{array}{c}-0.122531 \\
(0.000)\end{array}$ & $\begin{array}{c}0.0239018 \\
(0.650)\end{array}$ & $\begin{array}{c}0.0381483 \\
(0.595)\end{array}$ \\
\hline CONS & $\begin{array}{c}-7.48 \mathrm{E}+0 \\
(0.663)\end{array}$ & $\begin{array}{c}-3.02 E+0 \\
(0.053)\end{array}$ & $\begin{array}{c}-7.70 \mathrm{E}+00 \\
(0.645)\end{array}$ & $\begin{array}{c}1.03 E+01 \\
(0.345)\end{array}$ & $\begin{array}{c}1.37 E+01 \\
(0.133)\end{array}$ & $\begin{array}{c}9.79 \mathrm{E}+00 \\
(0.098)\end{array}$ & $\begin{array}{c}1.69 \mathrm{E}+01 \\
(0.102)\end{array}$ & $\begin{array}{c}-7.62 \mathrm{E}-01 \\
(0.889)\end{array}$ & $\begin{array}{c}7.20 \mathrm{E}+00 \\
(0.001)\end{array}$ & $\begin{array}{c}2.88 \mathrm{E}+00 \\
(0.821)\end{array}$ & $\begin{array}{c}-6.82 \mathrm{E}+00 \\
(0.528)\end{array}$ \\
\hline$R^{2}$ & 0.7101 & 0.4448 & 0.077 & 0.3375 & 0.245 & 0.2802 & 0.3872 & 0.6288 & 0.8081 & 0.4103 & 0.2704 \\
\hline
\end{tabular}

INFL, inflation; GFCF, gross fixed capital formation; DC, domestic credit; OC, Openness of a country 
and stock exchanges to meet the financial needs and also raise capital required for expanding operations as the economy grows.

Southern African Development Community economies can benefit from financial intermediation by strengthening their weak financial institutions, resolving their pathetic institutional and structural problems. Countries in SADC should make use of cross-border financial institutions to gain expansion in sector contribution. Reforms, such as entering economic integration, development of financial systems 'DFIs', monetary union and addressing structural and institutional problems, are necessary preconditions of stemming optimal gains as a positive relationship was found in SADC.

Furthermore, FS reforms in SADC should include improving the legal frameworks and enabling information sharing among financial institutions on creditworthiness of borrowers as well as increasing the availability of long-term loanable resources through stock markets, insurance companies and pension funds.

Inflation was found to be significant and also negative, showing that persistently high inflation has an adverse impact on economic growth in the region. The recommendation is that governments in SADC should continue to curb inflation and try to bring it down to sustainable levels where economic growth can take place.

From the empirical analysis, openness of a country was significant and positive; SADC countries should therefore encourage intra-SADC trade as this would be beneficial for domestic growth and growth of the region. In terms of GFCF, SADC countries should invest in key sectors that would contribute positively to the economic growth in the region.

Seemingly unrelated regression estimators results presented a negative link connecting FS development and economic growth in three SADC countries (Swaziland, Zambia and Zimbabwe). The recommendation is that the above-mentioned states should not solely rely on FS for economic growth to take place but they should also consider other sectors that can enhance growth such as agriculture, mining and tourism among other sectors.

Above all, SADC should create a conducive macroeconomic environment. A well-functioning financial system requires fiscal discipline and a stable macroeconomic environment. As noted by Rateiwa and Aziakpono (2017), monetary and fiscal policies affect the taxation of financial intermediaries and provision of financial services.

\section{Acknowledgements Competing interests}

The authors declare that they have no financial or personal relationships that may have inappropriately influenced them in writing this article.

\section{Authors' contributions}

S.A. was responsible for the econometric modelling and data analysis. C.M. was responsible for the background info, literature and data analysis. C.N. was responsible for the introduction, literature review, data presentation and analysis. P.1.R. was responsible for the literature review, review of methodology and overall supervision of the document.

\section{Funding information}

This research received no specific grant from any funding agency in the public, commercial or not-for-profit sectors.

\section{Data availability statement}

Data sharing is not applicable to this article as no new data were created or analysed in this study.

\section{Disclaimer}

The views and opinions expressed in this article are those of the authors and do not necessarily reflect the official policy or position of any affiliated agency of the authors.

\section{References}

Allen, S. \& Ndikumana, L., 1998, Financial intermediation and economic growth in southern Africa, Working Paper 1998-004B, The Federal Reserve Bank of ST Louis, ST Louis, Missouri.

Allen, F., Otchere, I. \& Senbet, L.W., 2011, 'African financial systems: A review', Review of Development Finance 1(2), 79-113. https://doi.org/10.1016/j.rdf.2011.03.003

Anyanwu, C.M., 2010, 'An overview of current banking sector reforms and the real sector of the Nigerian economy', Central Bank of Nigeria (CBN) Economic and Financial Review 48(4), 31-40.

Ofori-Appiah, E.D., 2016, 'The nexus between financial development and economic growth: Empirical evidence from Ghana', Post graduate theses/dissertations submitted to the College of Arts and Social Sciences, Ghana, viewed n.d., from http://ir.knust.edu.gh/xmlui/handle/123456789/10361?show=full.

Arayssi, M. \& Fakih, A., 2017, 'The finance-growth nexus, again: New evidence from Kenya', Economic Issues Journal Articles 22(2), 33-59.

Bara, A. \& Mudzingiri, C., 2016, 'Financial innovation and economic growth: Evidence from Zimbabwe', Investment Management and Financial Innovations 13(2), 65-75. https://doi.org/10.21511/imfi.13(2).2016.07

Barajas, A., 2016, 'The finance and growth nexus re-examined: Do all countries benefit equally?', Journal of Banking and Financial Economics 1(5), 5-38.

Bist, P.J., 2018, 'Financial development and economic growth: Evidence from a panel of 16 African and non-African low-income countries', Cogent Economics \& Finance 6(1), 1-17. https://doi.org/10.1080/23322039.2018.1449780

Cappiello, L., Kadareja, A., Sørensen, C.K. \& Protopapa, M., 2010, Do bank loans and credit standards have an effect on output? A panel approach for the Euro area, European Central Bank Working Paper Series, No 1150 /January, European Central Bank, Frankfurt.

Chinedua, N. \& Amaka, M.G., 2015, 'Financial development and economic growth nexus in Nigeria', IOSR Journal of Economics and Finance 6(4), 49-56.

Chisunga, D., 2015, 'Causal relationship between financial sector development and economic growth: A case of Zimbabwe', IOSR Journal of Business and Management $17(1), 1-12$

Committee of Central Bank Governors in SADC, 2012, SADC financial systems: Structures, policies and markets, Secretariat of the Committee of Central Bank Governors in SADC, Pretoria.

Demetriades, O.P. \& James, G.A., 2011, 'Finance and growth in Africa: The broken link', Economic Letters 113(3), 263-265. https://doi.org/10.2139/ssrn.1892274

Estrada, G., Park, D. \& Kamayandi, A., 2010, Financial Development and Economic Growth in Developing Asia, ADB Economics Working Paper Series No. 233, Asian Development Bank, Manila, Philippines.

FitzGerald, V., 2006, Financial development and economic growth: A critical view, A Background paper for World Economic and Social Survey, Oxford University, Oxford.

Greenwood, J., Sanchez, J. \& Wang, C., 2010, 'Financing development: The role of information costs', The American Economic Review 1(10), 167-191. https://doi. org/10.20955/wp.2010.024 
Gujarati, D.N. \& Porter, D.C., 2009, Basic econometrics, 5th edn., McGraw Hill International Edition, New York.

Iqbal, M., Ahmad, N. \& Hussain, Z., 2012, 'Impact of savings and credit on economic growth in Pakistan', Pakistan Journal of Social Sciences 32(1), 39-48.

International Monetary Fund, 2014 Angola: Second post-program monitoring IMF Country Report No. 14/81, March 2014, International Monetary Fund, Washington, D.C.

Karlsson, H. \& Mansson, K., 2015, Revisiting the nexus of the financial development and economic growth- Wavelet approach with a focus on Asian economies, Research Network Debate, Swedish Entrepreneurship Forum, Stockholm.

Kilimani, N., 2009, 'The link between financial development and economic growth in Uganda: A causality test', Paper presented at the Centre for the Study of African Economies (CSAE) Conference, 22-24th March 2009, Centre for the Study of African Economies, Oxford, United Kingdom.

King, R. \& Levine, R., 1993, 'Finance and growth: Schumpeter might be right', Quarterly Journal of Economics 108(3), 718-739. https://doi.org/10.2307/2118406

Kumar, R.R., 2011, 'Do remittances, exports and financial development matter for economic growth? A case study of Pakistan using bounds approach', Journal of International Academic Research 11(1), 18-26.

Law, S.H. \& Singh, N., 2014, 'Does too much finance harm economic growth?', Journal of Banking and Finance 4(1), 36-44. https://doi.org/10.1016/j.jbankfin.2013.12.020

Levine, R., 1997, 'Financial development and economic growth: Views and agenda', Journal of Economic Literature 35(2), 685-723.

Levine, R., 2005, 'Finance and growth: Theory and evidence', in Aghion, P. \& Durlauf, S. (eds.), Handbook of economic growth, vol. 1(b), pp. 865-894, Elsevier, Amsterdam, Netherlands.

Levine, R. Loayza, N. \& Beck, T., 2000, 'Financial intermediation and economic growth Causality and causes', Journal of Monetary Economics 46(1), 33-74. https://doi. org/10.1016/S0304-3932(00)00017-9

Mandiefe, E., 2015, 'Impact of financial development and economic growth', Journal of Development Economics 23(3), 33-54.

Mlambo, K., Kasekende, L. \& Murinde, V., 2012, 'Comparative overview of bank regulatory experiences and the impact on bank competition and intermediation efficiency in Africa' in V. Murinde (ed.), Bank Regulatory Reforms in Africa, Palgrave MacMillan, Basingstoke, United Kingdom.
Nouri, M. \& Samimi, A., 2011, 'The impact of monetary policy on economic growth in Iran', Middle-East Journal of Scientific Research 9(6), 740-743.

Odhiambo, N.M., 2005, 'Financial development and economic growth in Tanzania: A dynamic causality test', African Finance Journal 7(1), 1-17.

Odhiambo, N.M., 2007, 'Supply-leading versus demand-following hypothesis: Empirical evidence from three SSA countries', African Development Bank Review 19(2), 257-280. https://doi.org/10.1111/j.1467-8268.2007.00161.x

Odhiambo, N.M., 2010, 'Finance-investment-growth nexus in South Africa: An ARDLbounds testing procedure', Economic Change and Restructuring 43(3), 205-219. https://doi.org/10.1007/s10644-010-9085-5

Odhiambo, N.M., 2011, 'Financial deepening, capital inflows and economic growth nexus in Tanzania: A multivariate model', Journal of Social Science 28(1), 65-71. https://doi.org/10.1080/09718923.2011.11892929

Ogunmuyiwa, M.S. \& Ekone, A.F., 2010, 'Money supply-economic growth nexus in Nigeria', Journal of Social Sciences 22(3), 199-204. https://doi.org/10.1080/0971 8923.2010.11892802

Owolabi, A.U., 2014, 'Money supply, foreign exchange regimes and economic growth in Nigeria', Research Journal of Finance and Accounting 5(8), 121-129.

Rana, R. \& Barua, S., 2015, 'Development and economic growth: Evidence from a panel study on South Asian countries', Asian Economic and Financial Review 5(10), 1159-1173. https://doi.org/10.18488/journal.aefr/2015.5.10/102.10.1159.1173

Rateiwa, R. \& Aziakpono, M.J., 2017, 'Non-bank financial institutions and economic growth: Evidence from Africa's three largest economies', South African Journal of Economic and Management Sciences 20(1), 1-11. https://doi.org/10.4102/ sajems.v20i1.1545

Solow, R.M., 1956, 'A contribution to the theory of economic growth', The Quarterly Journal of Economics 70(1), 66-95. https://doi.org/10.2307/1884513

Sunde, T., 2011, 'Financial sector development and economic growth in Namibia', Journal of Emerging Trends in Economics and Management Sciences 1(2), 73-81.

Sunde, T., 2012, 'Financial sector development and economic growth nexus in South Africa', International Journal of Monetary Economics and Finance 5(1), 63-77. https://doi.org/10.1504/IJMEF.2012.044467

Uduakobong, I., 2014, 'Money supply and economic growth in Nigeria: An econometric analysis', Journal of Economics and Sustainable Development 5(12), 149-155. 